\title{
Diacronie
}

Studi di Storia Contemporanea

$\mathrm{N}^{\circ} 28,4 \mid 2016$

La voce del silenzio

\section{When Security Overrules Reason: McCarthyism in View of The Cases of Charles Chaplin and Lucille Ball}

\section{Erzsébet Árvay}

\section{(2) OpenEdition}

Journals

Electronic version

URL: http://journals.openedition.org/diacronie/4823

DOI: $10.4000 /$ diacronie.4823

ISSN: 2038-0925

Publisher

Association culturelle Diacronie

\section{Electronic reference}

Erzsébet Árvay, « When Security Overrules Reason: McCarthyism in View of The Cases of Charles Chaplin and Lucille Ball », Diacronie [Online], N²8, 4 | 2016, document 14, Online since 29 December 2016, connection on 10 December 2020. URL : http://journals.openedition.org/diacronie/4823 ; DOI https://doi.org/10.4000/diacronie.4823 


\title{
Diacronie
}

N. 28 | 4|2016 La voce del silenzio: intelligence, spionaggio e conflitto nel XX secolo

\section{4/}

\section{When Security Overrules Reason: McCarthyism in View of The Cases of Charles Chaplin and Lucille Ball}

\author{
Erzsébet ÁRVAY*
}

Counter-Intelligence operations as part of modern warfare serve the purpose of national security. However, these operations often target civilians, and therefore give rise to serious allegations which can have devastating effects on many people's life. The aim of this paper is to depict the mechanisms of the McCarthy era in view of the persecution of Charles Chaplin and Lucille Ball. Their cases aptly illustrate the controversial tactics and methods of McCarthyism in post-war America. To explore the networks used by authorities and actors of anti-communist operations, this paper exploits the archival sources of Chaplin's and Ball's cases which adds up to over two thousands pages in the records of the MI5 and the FBI. The fully detailed records give an insight into the impact of espionage accusations on civilians' lives and provide a good account of post-war American intelligence actions.

\section{Introduction}

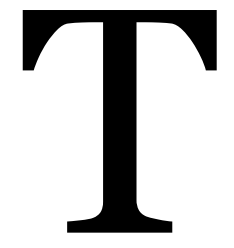

he aim of this paper is to depict the McCarthy era in view of the persecutions of Lucille Ball and Charles Chaplin and present how McCarthyism undermined the democratic principles of the USA. The reason for selecting the examples of Charles Chaplin and Lucille Ball is that they were equally well-known in the United States and both of them had immense influence on the American entertainment industry. Although the proceedings of the cases bore some similarities, the outcomes were distinctly different. Due to the wide 
popularity of the two comedians, the public records of their cases are fully detailed; therefore, they provide a good account of McCarthyism.

Charlie Chaplin was a British subject, however, he spent most of his life in the USA where he became an influential figure of the movie industry. Although the FBI tried to level charges against Chaplin, none of them was proven. In spite of this fact, he was the subject of several extensive investigations conducted by the FBI. The media and the public also unleashed attacks against him, and finally, he was forced to exile in Switzerland. The presented events and facts profusely illustrate the proceedings of the persecutions in the McCarthy era and their devastating effects on many people's life.

The other example is Lucille Ball's career. Lucille Ball became a popular television star almost at the same time that Joseph McCarthy started his Communist witch hunt. Millions of people watched her weekly comedy show, but her fame also drew the attention of anti-Communists. In the case of Lucille Ball, the process of the investigations differed from Chaplin's, thus they give a good insight into the machinery of McCarthyism. Although Lucille Ball's earlier career was not as significant as Chaplin's, during the time of the investigations she was more popular than Chaplin and this fact had a great impact on the outcomes. Besides the tremendous admiration of the public, Lucille's influential acquaintances featured an even greater support. By comparing and contrasting the two cases, the methods which characterise McCarthyism can be described. These persecution methods violated the democratic rights, damaged the reputation of innocent people, and fuelled the Communist scare. They aroused suspicion and paranoia, which led people to believe that there were reds under the bed.

\section{Prelude to the Second Red Scare}

In order to understand McCarthyism, it is necessary to take a look at the historical events that preceded Joe McCarthy's emergence. The limits of this paper do not allow for a deep analysis of the historical context, therefore, in this section I highlight the most significant events, providing an adequate understanding of the circumstances. Furthermore, I present relevant facts and details that are essential for the further discussion of McCarthyism.

In February 1946, George Kennan explained the incompatibility of the Soviet and the American outlook in the "Long Telegram": «USSR still lives in antagonistic "capitalist encirclement" » and "we have here a political force committed fanatically to 
the belief that with US there can be no permanent modus vivendi $»^{1}$. In 1947 , he also stated: "In these circumstances it is clear that the main element of any United States policy toward the Soviet Union must be that of long-term, patient but firm and vigilant containment of Russian expansive tendencies» ${ }^{2}$. Kennan's explanation of the ideological incompatibility inspired Truman's speech on 12 March 1947, in which he laid out the Truman Doctrine and formed the U.S. foreign policy in the early years of the Cold War. In November 1946, a temporary commission was set up to investigate the loyalty of government employees. Then, by the Executive Order 9835, a series of investigations were initiated in order to identify Communist elements ${ }^{3}$. The House Committee on Un-American Activities was created in 1938 and aimed at investigating subversive activities ${ }^{4}$. Although the HUAC was primarily targeted at Nazi factions, by the end of the 1940's, the Committee dealt almost exclusively with Communist activities.

On 9 February 1950 Joseph McCarthy, during his speech at a Republican Party event in Wheeling, West Virginia, started waving a paper and declared that it contained a list of 205 people who were card-carrying members of the Communist Party and were nonetheless officials of the U.S. government 5 . His words enhanced the American "paranoid style", borrowing the term from Richard Hofstadter whose words are the finest explanation of the hysteria evoked by McCarthy: «heated exaggeration, suspiciousness, and conspiratorial fantasy» ${ }^{6}$.

Meanwhile, the concept of "Red Channel" became widespread, which meant the assumed influence of Communists on television, radio and film. The USA had a strong reaction to Soviet propaganda and tried to keep Communists away from the entertainment industry through which millions of Americans could be reached. One of

\footnotetext{
${ }^{1}$ KENNAN, George, «Long Telegram», in Harry S. Truman Library and Museum, 22 February 1946, URL:

<http://www.trumanlibrary.org/whistlestop/study_collections/coldwar/documents/pdf/66.pdf $>$ [consulted on 10 September 2016].

${ }^{2}$ KENNAN, George, «The Source of the Soviet Conduct», in The History Guide, 7/1947, URL:

<http://www.historyguide.org/europe/kennan.html> [consulted on 12 September 2016].

3 JOHNSON, Paul, A History of the American People, London, Phoenix, 2004, p. 852.

4 FRIED, Albert, McCarthyism: The Great American Red Scare: A Documentary History, New York, Oxford UP, 1997, p. 16.

5 MCCARTHY, Joseph, «Speech at Wheeling, West Virginia», in Advances in the History of Rhetoric, 9 February 1950, URL: <http://www.advances.umd.edu/LincolnBirthday/mccarthy 1950.xml> [consulted on 14 April 2016].

6 HOFSTADTER, Richard, «The Paranoid Style in American Politics», in Harper's Magazine, 11/1964, URL: <http://harpers.org/archive/1964/11/the-paranoid-style-in-american-politics> [consulted on 25 August 2016].
} 
the many ways to achieve this aim was to blacklist employees who maintained Communist ties?.

The blacklisting started with the case of the Hollywood Ten. HUAC subpoenaed ten employees of the film industry, mostly screenwriters and directors, in order to clarify whether they were members of the Communist Party or not. The ten accused refused to answer the questions on the basis of the First Amendment, which protects the basic democratic right to freedom of speech. All of them were sentenced to imprisonment in $1951^{8}$.

The case of the Hollywood Ten launched a hysterical blacklisting. Artists were required to take loyalty oath, stating that they were neither members of the Communist Party nor Communist sympathisers. Hedda Hopper's statement reveals the high degree of hysteria present in contemporary society: «Those who aren't loyal should be put in concentration camps before it's too late»9. Hopper was probably not aware of the fact how such statement could intensify the Red Scare, especially among European immigrants. However, it is important to note that Hedda Hopper was perhaps the most famous gossip columnist at that time, and the fact that she spoke up for the antiCommunist purge shows that Joe McCarthy had more effective weapons in his armoury than truth.

\section{Charlie Chaplin: The Beginning of the Investigation}

The process of the investigations against Chaplin demonstrates the methods of persecutions and prosecutions in the era of Communist hysteria. The sources of this section are the declassified files of the FBI and the MI5 on Charlie Chaplin, which also contain several press clippings and private letters which reflect the public reaction to Chaplin's presumed Communist activities. My aim is not to determine whether Chaplin was Communist or not. Furthermore, it is not my intention to refute the legality of these investigations. Considering the historical context, it is understandable why the investigations were launched. However, the methods of the legal proceedings against Chaplin are disputable.

\footnotetext{
7 DOHERTY, Thomas, Cold War, Cool Medium: Television, McCarthyism, and American Culture, New York, Columbia UP, 2003, pp. 8-21.

8 Ibidem, p. 21.

9 MITCHELL, Greg, «Hollywood's Wildest Night Ever: When Legends Faced Off in a Political Showdown», in The Nation, 20 October 2012, URL:

$<$ http://www.thenation.com/blog/170709/hollywoods-wildest-night-ever-when-legends-facedpolitical-showdown $>$ [consulted on 9 September 2016].
} 
Chaplin arrived in the USA in 1910 as a British subject ${ }^{10}$ where he soon gained immense popularity by his short films ${ }^{11}$. From the files of the FBI, we can learn that Chaplin's fame attracted not only the attention of the press but also the attention of the informants for the FBI. Chaplin was kept under surveillance from 1922 to 1978, and nearly half of the open files are in connection with his assumed Communists ${ }^{12}$.

The first records on Chaplin's alleged Communist activities are from 1922. These records reveal a reception held by Chaplin for William Z. Foster who was the general Secretary of the Communist Party of USA. The event gave rise to the suspicion that Chaplin wanted to serve the Communist propaganda by his influence on the film industry $^{13}$. However, it seems clearly that the censorship of that time, which was tied to William Hays, could prohibit any kind of subversive propaganda ${ }^{14}$. Thus, Chaplin's films did not present a serious threat against the American public.

From the 1920's there is another record which is about a donation of 1000 dollars to the Communist Party of the United States of America. Chaplin was considered as the source of this donation, however, we can also learn that there was no clear evidence of this assumption: "It is generally understood among the Communists that the money came from Charlie Chaplin"15. The importance of this sentence lies in the fact that the FBI continued to use this practice, namely imputing Communist activities to Chaplin without sufficient evidence.

From the beginning of the 1940's, the FBI recorded crucial information against Chaplin. On 3 December 1942, Chaplin gave a speech at the Russian War Relief Dinner in which he stated: «I am not a Communist but I am proud to say that I feel pretty proCommunist» ${ }^{16}$. This sentence and his speaking up for the Communist ally of the USA are repeatedly mentioned throughout the records as if these lines had been a formal testimony by him. However, it is necessary to consider Chaplin's understanding of Communism in order to see the meanings of his speech. Chaplin was interviewed on 17 April 1948 by the Immigration and Naturalization Service when he admitted under oath that: «I never read a book about Communism. I don't know anything about it. I

\footnotetext{
10 "Charlie Chaplin Part 08 of 10», in FBI: The Vault, p. 80 URL: <http://vault.fbi.gov/charliechaplin/charlie-chaplin-part-08-of-10/view $>$ [consulted on 22 July 2016].

${ }^{11}$ CHAPLIN, Charles, My Autobiography, London, Penguin Classics, 2003, p. 152.

12 "Charlie Chaplin», in FBI: The Vault, URL: <http://vault.fbi.gov/charlie-chaplin> [consulted on 7 September 2016].

13 «Charlie Chaplin Part 07 of 10», in FBI: The Vault, pp. 4-7, URL:

$<$ http://vault.fbi.gov/charliechaplin/charlie-chaplin-part-o7-of-10/view> [consulted on 22 July 2016].

14 Ibidem, p.9.

15 Ibidem, p. 12.

16 Ibidem, p. 15.
} 
never read Karl Marx or anything like that. My interpretation of Communist was Russia»17. During the interview he also stated:

Frankly, I don't know anything about the Communist way of life. I must say that, but I must say this, I don't see why we can't have peace with Russia. Their way of life - I am not interested in their ideology, I assure you. I assure you. I don't know whether you believe me or not, but I am not. I am interested to the point where they say they want peace, and I don't see why we can't have peace here. I don't see why we can't have trade relationship and ameliorate matters and so forth and avoid a world war ${ }^{18}$.

To understand Chaplin's outlook on American foreign policy and on the USSR, we have to consider the background of his perspective. Chaplin settled down in the USA in October $1912^{19}$, he lived through the First World War there and experienced it as a European immigrant. He despised the tactic of the USA during the First World War, namely «let them both bleed white $»^{20}$. In his autobiography, Chaplin says: «in 1915 the United States alleged that it was "too proud to fight" ${ }^{21}$. As the forces of the European great powers had started to decline, the United States entered the war in 1917 with the intention of fighting until the capitulation of the enemies.

In his autobiography, Chaplin also writes: «Many were rather glad that the war had been declared, for now we would show the Germans» ${ }^{22}$. Although Chaplin lived in the USA, he was European and he could not think of the war in any other way than as a «ruthless slaughter and destruction» ${ }^{23}$. Chaplin realized that the USA was largely responsible for the outcome of the war and for «the ill-fated Versailles Treaty» ${ }^{24}$. After the First World War, Chaplin stated: «the Allies had won - whatever that meant. But they were not sure that they had won the peace. One thing was sure, that civilization as we had known it would never be the same - that era had gone»25. In 1921, Chaplin visited London, Paris and Berlin: «Berlin was depressing. It still had an atmosphere of defeat, with its tragic aftermath of armless and legless soldiers begging on almost every

17 «Charlie Chaplin Part 07 of 10», in FBI: The Vault, p. 241, URL: <http://vault.fbi.gov/charliechaplin/charlie-chaplin-part-07-of-10/view $>$ [consulted on 22 July 2016].

18 «Charlie Chaplin Part 08 of 10», in FBI: The Vault, p. 6, URL: <http://vault.fbi.gov/charliechaplin/charlie-chaplin-part-08-of-10/view $>$ [consulted on 22 July 2016].

19 «Charlie Chaplin Part o9 of 10», in FBI: The Vault, p. 33, URL: <http://vault.fbi.gov/charliechaplin/charlie-chaplin-part-09-of-10/view $>$ [consulted on 22 July 2016].

${ }^{20}$ CHAPLIN, Charles, op. cit., p. 402.

${ }^{21}$ Ibidem, p. 212.

${ }^{22}$ Ibidem, p. 158.

23 Ibidem, p. 223.

24 Ibidem, p. 191.

25 Ibidem, p. 224. 
street corner ${ }^{26}$. We can see that Chaplin knew the damages caused by the Great War, and he considered the USA responsible for these damages.

His experience of the First World War led him to stand up for the Soviet Union in the Second World War. In his autobiography, Chaplin explains that in the early years of the Second World War he felt that the aim of the USA was to let both Nazi Germany and Soviet Russia bleed, in spite of the fact that Soviet Russia and the USA were allies. Chaplin believed in the necessity of the second front, since Russia desperately needed help against Nazi Germany ${ }^{27}$. However, he could not understand what was happening in Europe since he had not been living there for 30 years at that time. In 1948, he said: «we were all together in the Allied cause and fighting for democracy and they were our comrades» and «I personally believe and honestly believed they were doing a splendid job and I believe if it hadn't been for Russia we might have had these Nazis over here and I firmly believe that and I don't see any reason for any antagonism now against Russia» ${ }^{28}$. Thus, we can see that Chaplin did not have realistic and profound knowledge about Communism or Soviet Russia and he could not understand the political situation during and after the Second World War.

The connection between the FBI and the press is also worth considering. From the records of the FBI, we can learn that the FBI provided Louella Parsons and Hedda Hopper with information about Chaplin ${ }^{29}$. Parsons and Hopper were well-known gossip columnists and by sending them unproven allegations, the FBI could draw their, and thus the public's attention to the Communist accusations against Chaplin. However, it is also interesting that although the FBI was aware of how gossip columnists got their information, the FBI took the press seriously and recorded their accusations against Chaplin. For example, on 27 December 1943 Hedda Hopper wrote: «From things I have learned Charlie [Chaplin] who contributed $\$ 25,000$ to the Communist cause...»30. Hopper's lines appear several times in the FBI records, although after monitoring Chaplin's bank account, it was recorded that there was no proof of the contribution.

\footnotetext{
${ }^{26}$ Ibidem, p. 275.

27 Ibidem, p. 403.

28 «Charlie Chaplin Part o8 of 10», in FBI: The Vault, pp. 3-9, URL:

<http://vault.fbi.gov/charlie-chaplin/charlie-chaplin-part-o8-of-10/view> [consulted on 22 July 2016].

29 «Charlie Chaplin Part 07 of 10», in FBI: The Vault, pp. 95-102, URL:

<http://vault.fbi.gov/charlie-chaplin/charlie-chaplin-part-o7-of-10/view> [consulted on 22 July 2016].

30 Ibidem, p. 46.
} 
These records led to the preparation of a Security Index card ${ }^{31}$, which proves that Chaplin was considered as a security risk. Furthermore, investigations were launched on Chaplin's assumed Soviet espionage activities ${ }^{2}$. However, a record which was made on 5 July 1949 states that they had no evidence of Chaplin's espionage activities33. In addition, the FBI could not find any proof of Chaplin's affiliation with the CPUSA 34 . Two days before McCarthy's speech at Wheeling, on 7 February 1950, a memorandum was made which recommended closing the investigations of Chaplin's unproven Communist affiliation.

However, during the second half of 1950 several letters were sent to J. Edgar Hoover by unidentified senders who demanded the deportation of Charlie Chaplin. On 18 August 1950, a handwritten letter was sent to the FBI asking: «How is it that Charlie Chaplin isn't deported»35. This letter was followed by another saying: «why he had not been deported»36. Following the letters, on 15 January 1951, a request was made to reopen Chaplin's case ${ }^{37}$.

The deportation of Chaplin and the possible prevention of his re-entry to the USA were taken much more seriously after January 1951. The FBI made records of Chaplin's application for a re-entry permit and requested information about Chaplin's planned trips abroad ${ }^{8}$. In August 1952, the FBI was informed that Chaplin would possibly leave the country in September $195^{39}$. Although the Immigration and Naturalization Service did not have enough evidence to prevent Chaplin's re-entry, the FBI files recorded the attempt of INS to exclude Chaplin from the USA on the charges of perjury ${ }^{40}$. Charles Chaplin probably did not know anything about these attempts, and he left the USA on 17 September $195^{41}$.

As we can see, the investigations against Charles Chaplin were intensifying from the 1920's to the end of 1940's. After February 1950, we can witness that a more aggressive surveillance was conducted against Chaplin. The quoted letters and the attempt to

${ }^{31}$ «Charlie Chaplin Part 07 of 10», in FBI: The Vault, p. 200, URL:

<http://vault.fbi.gov/charlie-chaplin/charlie-chaplin-part-07-of-10/view> [consulted on 22 July 2016].

32 Ibidem, p. 203.

33 "Charlie Chaplin Part 08 of 10», in FBI: The Vault, p. 19, URL: <http://vault.fbi.gov/charliechaplin/charlie-chaplin-part-08-of-10/view> [consulted on 22 July 2016].

34 Ibidem, p. 37.

35 Ibidem, p. 62.

${ }^{36}$ Ibidem, p. 65.

37 Ibidem, p. 64.

${ }^{38}$ Ibidem, p. 90.

39 Ibidem, p. 93.

40 Ibidem, pp. 130-131.

${ }^{41}$ «Charlie Chaplin Part 09 of 10», in FBI: The Vault, p. 39, URL: <http://vault.fbi.gov/charliechaplin/charlie-chaplin-part-09-of-10/view $>$ [consulted on 22 July 2016]. 
deliberately prevent Chaplin's re-entry show an extreme reaction to the accusations levelled against him. Although these accusations were not proven, Chaplin's departure in September 1952 gave the opportunity to ban him from the USA.

\section{Exile}

Preventing Chaplin's re-entry to the USA could be attained upon two charges. The first was the aforementioned charge of perjury and the second was to prove his moral turpitude. To find enough evidence, authorities worked on the Paternity Case against Chaplin, which was previously closed in $1945^{42}$. In 1943 Joan Barry stated that Chaplin was the father of her unborn child and filed a legal procedure against Chaplin. 43 Although a blood test was carried out which proved that Chaplin could not be the father, he had to pay a weekly child support until the child turned 2144. The Paternity Case adds up to over 1200 pages in the records of the FBI on Chaplin, but it is considered as a separate issue from the Communist activities. However, the fact that the FBI tried to use this case against Chaplin proves that the investigation was launched not to prevent a possible Communist threat against the USA, but to simply prevent Chaplin's re-entry. In this case Chaplin was deemed to be the threat, not Communism.

This fact can be also proved by the investigation on Chaplin's descent. Already in September 1946, a record was made that Chaplin was possibly a descendant of an Eastern European family, named Thonstein45. Not only the FBI but the MI5 also carried out investigations on this case. The first record of the MI5 on Chaplin was made on 22 September 1952, after his departure from the USA. The notes of MI5 present an utterly different opinion about Chaplin's case: «I scarcely think that this is of any security significance» 46 and «I should prefer to reply that we have no reliable information of security interest»47. As we see, the MI5 did not consider Chaplin as a security risk, furthermore, it firmly opposed the FBI. The records say: «we do consider these allegations to be unreliable and have assessed the security significance of Chaplin accordingly» 48 and refers to Chaplin as «one of the victims of McCarthyism»49.

42 CHAPLIN, Charles, op. citi, p. 425.

43 Ibidem, p. 415

44 Ibidem, p. 425.

45 «Charlie Chaplin Part 07 of 10», in FBI: The Vault, p. 37, URL: <http://vault.fbi.gov/charliechaplin/charlie-chaplin-part-07-of-10/view $>$ [consulted on 22 July 2016].

46 «KV2/3700», in The National Archives, 17 February 2012, p. 5.

47 Ibidem, p. 6.

48 Ibidem, p. 7.

49 Ibidem, p. 23. 
The MI5 was also unable to confirm further accusations upon which any charges could be levelled against Chaplin. Therefore, Chaplin was accused of falling into arrears with his taxes, totalling 500.000 pounds. Chaplin referred to this charge as «revengeful and continuous persecution ${ }^{50}$. Thus, it is clear that the FBI desperately tried to gain any facts and information which could be used against Charlie Chaplin.

Seemingly these attacks on Chaplin were pointless, since it was known that he did not want to re-enter the USA. It was reported in January 1953 that Chaplin had decided to buy a villa in Switzerland, furthermore, he had enrolled his children in school in Switzerland ${ }^{51}$. Another report from February 1953 reflects that Chaplin wanted to sell his Hollywood estate52 and later, a report from April 1953 says that "Chaplin has surrendered his re-entry permit»53. These reports are the evidence that Chaplin did not intend to return to the USA.

Although the FBI possessed this information, they still considered Chaplin a security risk. It was claimed by the INS that Chaplin returned his re-entry permit in order to "give the impression he is not returning to the United States while actually he may attempt to return unnoticed»54. The only logical explanation of this assumption is that in this way the FBI did not have to close Chaplin's case and he could be kept under surveillance until his death.

Twenty years after Chaplin had left the USA, unsubstantiated accusations were still made against him. In January 1972, a letter was sent to J. Edgar Hoover in which the sender presented his opinion about Chaplin's short visit to the USA to accept an award. The sender stated: «This Communist bastard has turned his back on this land of ours and took millions of dollars out of this country when he went to live in Switzerland»55. Instead of denying these nonsense accusations, in his response, Hoover seemingly accepted the false assumptions ${ }^{5}$. However, the fact that Chaplin was awarded by the American film industry demonstrate that the public opinion about him had changed over the years. It is interesting to consider that although Chaplin was given the Honorary Academy Award, Chaplin was still considered as an alien in the USA. Geraldine Chaplin evokes this event in a documentary about his father: «When he did

\footnotetext{
50 Ibidem, p. 25.

${ }^{1}$ «Charlie Chaplin part 10 of 10», in FBI: The Vault, p. 16, URL: <http://vault.fbi.gov/charliechaplin/charlie-chaplin-part-10-of-10/view > [consulted on 22 July 2016].

$5^{2}$ Ibidem, p. 58.

53 Ibidem, p. 47.

54 Ibidem, p. 80.

55 Ibidem, p. 165.

${ }^{56}$ Ibidem, p. 166.
} 
go back to the States, they gave him a visa of only 10 days »57. Although the case of the visa clearly demonstrates that Chaplin was still only a guest in the USA, Geraldine Chaplin also recalls the reaction of his father, which gives another interpretation of the case: «He was thrilled. He said: "They're still scared of me"»58.

Charlie Chaplin's case demonstrates how unproven Communist accusations developed into personal attacks and character slanders against him during the McCarthy era. His testimony proves that it is very unlikely that he had any ties with Communists, and this fact was also stated by the MI5. Although the FBI had no sufficient evidence against Chaplin, he was kept under surveillance for more than 50 years, until his death.

\section{Lucille Ball: A Registered Communist}

Lucille Ball was born in 1911 Jamestown, New York. She left high school at the age of 15 in order to start an acting career. Ball arrived in California in 1933 and became an actress at Columbia Pictures and later at RKO, where she met Desi Arnaz. Arnaz, who was the only son of a Cuban senator, fled from Cuba after the revolution led by Fulgencio Batista, had broken out. After Lucille and Desi married, they formed the Desilu Productions and launched their famous weekly television show I Love Lucy in October $1951^{59}$.

The show gained immense popularity and Lucille became the «First Lady of Television» 60 , which later had a great effect on Ball's case. The two most important proofs of her popularity are the sponsors and the ratings. Philip Morris Company invested 8 million dollars in Lucille's show, which meant an enormous amount at that time $^{61}$. Furthermore, according to the ratings, on 19 January 1953, approximately 44 million Americans watched the $5^{1 \text { th }}$ episode of the show, however, only 29 million Americans watched Eisenhower's inauguration the following day on 20 January 1953 ,

57 HIRT, Beat, ZENONI, Felice, Charlie Chaplin: The Forgotten Years, Mesch \& Ugge AG, Switzerland, 2003, 44'.

${ }^{8}$ Ibidem.

59 ANDREWS, Bart, The Story of "I Love Lucy", New York, Fawcett Popular Library, 1977, pp. 23-30.

${ }^{60}$ BRIOUX, Bill, Truth and Rumors: The Reality Behind TV's Most Famous Myths, Westport, Praeger, 2008, p. 33.

${ }^{61}$ DOHERTY, Thomas, Cold War, Cool Medium: Television, McCarthyism, and American

Culture, New York, Columbia UP, 2003, p. 50. 
and even less Americans were interested in the coronation ceremony of Queen Elizabeth II in June $1953^{62}$.

However, it was not Lucille's television program which drew the attention of the FBI. Ball was interviewed by the HUAC about her assumed Communist activities in 1952 and later on 4 September 1953. The accusations were based on material proof and testimonies of several witnesses. In 1953, these documents had already been in the possession of the FBI for more than 10 years ${ }^{63}$. A record of the FBI shows that in 1952 Lucille Ball's voter registration affidavit revealed that she had registered to vote for the Communist Party in $1936^{64}$. Although the affidavit of registration did not mean that she actually voted for the Communist Party, she was suspected of Communist affiliation.

Further evidence against Lucille was a certificate which stated that she had signed to sponsor Emil Freed, a candidate of the Communist Party ${ }^{65}$, and her membership in the Committee for the First Amendment. In 1947, Ball was against the HUAC hearings of the Hollywood Ten and she publicly stated: «The way to [defend the Constitution] is not by shutting up the man you disagree with». From the FBI's perspective, defending the Hollywood Ten was equal to a confession of Communist affiliation ${ }^{66}$.

According to Rena M. Vale's testimony, in 1937 a Communist meeting was held at Lucille Ball's home. Vale stated that although Lucille had not been present, she had known «the character of the meeting and approved of its taking place in her home» ${ }^{67}$. In 1953, an affidavit was found, signed by Lucille, which revealed that previously she had been a delegate of the State Committee of the CPUSA. Further incriminating evidence was that Lucille had made several radio broadcasts in the early 1940's which later turned out to be tied to the Communist Party68.

Lucille had to clear herself of the Communist charges. After she had been interviewed by the HUAC in April 1952, the FBI made a record saying they have no sufficient evidence of Lucille being a member of the Communist Party or being a sympathiser of Communist ideology. This record also recommended closing Lucille's case $^{69}$. In spite of the closed status of her case, we can find a record which forecast

\footnotetext{
62 ANDREWS, Bart, op. cit., pp. 17,104.

63 DOHERTY, Thomas, op. cit., p. 53.

64 «Lucille Ball Part 01 of 01», in FBI: The Vault, p. 58, URL: <http://vault.fbi.gov/lucilleball/lucille-ball-part-01-of-01/view> [consulted on 26 August 2016].

65 «Lucille Ball Part 01 of 01», in FBI: The Vault, p. 12, URL: <http://vault.fbi.gov/lucilleball/lucille-ball-part-o1-of-o1/view> [consulted on 26 August 2016].

66 DOHERTY, Thomas, op. cit., p. 53.

67 «Lucille Ball Part 01 of 01», in FBI: The Vault, p. 15, URL: <http://vault.fbi.gov/lucille-

ball/lucille-ball-part-01-of-o1/view> [consulted on 26 August 2016].

${ }^{68}$ Ibidem, pp. 30-125.

69 Ibidem, pp. 59-60.
} 
further inquiries about Lucille. The National Heart Association selected Lucille and Desi for "Mr. and Mrs. Heart of 1953", however, the association withdrew the decision in December 1952 because they got information about the possible HUAC hearings of Ball7o. This fact demonstrates that an assumption of a HUAC hearing was enough to destroy the reputation of a person.

The second interview was held on 4 September 1953. From Ball's testimony, we can learn that she refuted the allegations and stated that her grandfather, Fred Hunt had made her sign the affidavit of registration. To explain why she had signed the paper, Lucille stated that his grandfather had been a Socialist and he had had several strokes previously therefore Lucille and her family had tried to avoid making him excited. She rebutted being Communist or having any ties with the Communist Party. Although she registered to vote for the Communist Party in 1936, she did not vote accordingly. Lucille said: «It just didn't seem like an important, awful thing to do, like it does these days ${ }^{71}$. So Lucille did not think that the affidavit could cause any harm to her. To support her statement, she indicated that she had voted for Eisenhower ${ }^{72}$ and previously had been a supporter of Roosevelt73.

During the hearing Lucille stated she did not know about being a delegate of the State Committee of the Communist Party. William Wheeler, the investigator of the HUAC, presented the signed affidavit but Ball made references to her grandfather again saying that he had signed the paper. Lucille had the same reaction when she was confronted with Rena M. Vale's testimony. Ball refuted the allegation that she had knowledge of the meeting. At the end of the hearing, she firmly declared that she had no Communist ties, she did not contributed money or attend any meeting which was in connection with the Communist Party, thus she denied all the Communist accusations 74 .

The FBI accepted what Lucille stated and thus she could clear herself of the charges of Communist sympathies. However, Lucille's story did not end at that point. Two days after the hearing, on 6 September 1953, Walter Winchell, who was a well-known radio commentator, made the accusations of the HUAC against Lucille public: «While the House Committee on Un-American Activities was holding secret sessions in California, the most popular of all television stars was confronted with her membership in the

\footnotetext{
70 Ibidem, p. 61.

71 Ibidem, pp. 121-124.

${ }^{2}$ DOHERTY, Thomas, op. cit., p. 54.

73 «Lucille Ball Part 01 of 01 », in FBI: The Vault, p. 125, URL: <http://vault.fbi.gov/lucille-

ball/lucille-ball-part-01-of-01/view $>$ [consulted on 26 August 2016].

74 Ibidem, pp. 122-123.
} 
Communist Party»75. By this line, Winchell aroused the public's suspicion against Lucille Ball.

75 DOHERTY, Thomas, op. cit., p. 53. 


\section{Public Reaction}

The news about the HUAC hearing of Lucille Ball rapidly spread across the USA in September $1953^{76}$. The execution of the Rosenbergs preceded the news only by two months. Thus, we can see that the press managed to attack Lucille when the Communist hysteria reached its climax. A few hours after Winchell's broadcast on 6 September 1953, Ken Morgan, the PR representative of the Desilu Production, and Howard Strickling, the publicity director of MGM arrived at Lucille's estate ${ }^{77}$. Their instant arrival presents the gravity of the fact that the HUAC hearing went public, although Lucille had already cleared herself. Strickling was financially interested in the case since MGM invested 2 million dollars in a Desilu Production in that year, and he knew that «the era of Joe McCarthy and of the infamous Senate hearings was in full swing, and an accusation such as Winchell's could spell the end of the entire Desilu empire ${ }^{78}$.

Desi Arnaz had already had knowledge of Winchell's intentions two weeks before the broadcast. As he stated: «J. Edgar Hoover told me about it at a racetrack. He said there was nothing he could do $\gg 79$. A press clipping in the records of the FBI reveals that the second HUAC hearing was conducted because the Committee also had gained information about the broadcast before it was aired ${ }^{80}$. The HUAC wanted to be prepared with the sufficient information, however, in this case, Lucille had to face the public.

Lucille knew that unfavourable publicity could destroy her career and the I Love Lucy show as well. Moreover, the failure would have caused the bankruptcy of the sponsors. This also meant that she had to persuade the sponsors of her innocence before they would back out of the show. The Philip Morris Company was the most significant sponsor of the Desilu Production, which had 8 million dollars' worth of interest in the success of Lucille Ball. The reaction of the Company to the news was extremely favourable to the Desilu Production: «If all the facts are as they now are, we're behind you one hundred percent ${ }^{81}$. The Vice President of CBS, Harry Ackerman

\footnotetext{
${ }^{76}$ Ibidem, p. 52.

77 ANDREWS, Bart, op. cit., p. 118.

78 Ibidem, p. 119.

79 ANDREWS, Bart, op. cit., p. 119.

80 «Lucille Ball Part 01 of 01 », in FBI: The Vault, p. 71, URL: <http://vault.fbi.gov/lucilleball/lucille-ball-part-01-of-01/view $>$ [consulted on 26 August 2016].

81 ANDREWS, Bart, op. cit., p. 121.
} 
also backed Lucille: «Miss Ball is not and has never been a Communist. People seem to feel this thing is silly, not serious, and they all love Lucy»82.

In September 1953, Winchell received a letter in which the sender expressed his doubts about Lucille and stated: «the show should be called I LOATHE LUCY and every real American feels that way too» ${ }^{83}$. Luckily for Lucille, the public had a different opinion, which was noticeable already at the shooting of the first episode of the new season of I Love Lucy, on 11 September 1953. Before the shooting, Desi made a short speech in front of the live studio audience: «I was kicked out of Cuba because of Communism. We both despise Communists and everything they stand for». He referred to Lucille as his «favourite redhead - in fact, that's the only thing red about her, and even that's not legitimate». By these lines, he could win the support of the audience. The following day, Ball and Arnaz held a press conference at their home ranch where they managed to clear Lucille of the accusations ${ }^{84}$.

Meanwhile, Lucille telephoned her old friend Hedda Hopper, who penned an article in support of Ball ${ }^{85}$. In the person of Hopper, the most influential gossip columnist spoke up for Lucille. Her article kept up a good image of Lucille. Hedda did not detail all the evidence and she presented the case one-sidedly. The article was obviously written in order to arouse sympathy.

The press published Lucille's affidavit of registration on 11 September and a couple of days later, her testimony went also public. It is also significant that Donald Jackson, member of the HUAC, held a press conference where he stated that Lucille «had never had a role in the Communist Party» ${ }^{86}$. Sharing these documents with the public was a wise decision of Lucille's due to the fact that in this way the public did not feel that Lucille had something to hide, in other words, it gave the impression of innocence. Furthermore, Donald Jackson's unprecedented statement helped Lucille greatly in clarifying herself.

On 13 September 1953, one week after Winchell had started the public accusations, he claimed in his Sunday broadcast: «The Lucille Ball story which rocked the nation has had a very happy ending» ${ }^{87}$. He said that apart from Donald Jackson, all the

\footnotetext{
82 DOHERTY, Thomas, op. cit., p. 57.

83 «Lucille Ball Part 01 of 01», in FBI: The Vault, p. 93, URL: <http://vault.fbi.gov/lucilleball/lucille-ball-part-01-of-o1/view> [consulted on 26 August 2016].

84 ANDREWS, Bart, op. cit., pp. 122-124.

85 «Lucille Ball Part 01 of 01», in FBI: The Vault, pp. 70-71, URL: <http://vault.fbi.gov/lucilleball/lucille-ball-part-01-of-01/view> [consulted on 26 August 2016].

86 DOHERTY, Thomas, op. cit., p. 54; «Lucille Ball Part 01 of 01», in FBI: The Vault, pp. 78-82, URL: <http://vault.fbi.gov/lucille-ball/lucille-ball-part-01-of-o1/view> [consulted on 26 August 2016].

87 DOHERTY, Thomas, op. cit., p. 57.
} 
members of HUAC, J. Edgar Hoover and the FBI cleared Lucille ${ }^{88}$. Ball, in fact, was cleared and she managed to maintain her success. According to the ratings, approximately 50 million viewers tuned in each Monday to I Love Lucy in that season $^{89}$.

As we see, the Communist hysteria caused little harm to Lucille Ball. Two months after her case had leaked out, she was selected as "the Woman of the Year", and on 26 November 1953, she had dinner in President Eisenhower's company in the White House where she and Desi entertained the company ${ }^{90}$. In December 1954, the FBI stated that Lucille was not placed on Security Index and closed her case ${ }^{91}$. It is important to consider Ed Sullivan's remark on the case:

It's a singularly fortunate thing for Lucille Ball that she's been a weekly visitor to millions of American living rooms. In those Monday night visits, people have come to know her well. TV cameras being as revealing as they are, so the jury of Public Opinion is an informed jury as it renders its verdict on a silly thing she did seventeen years ago 92 .

The statement reveals that the outcome of Lucille Ball's case was substantially influenced by her fame. Her show connected Lucille with millions of viewers, and more importantly with powerful acquaintances. But for Lucille's popularity, the support of sponsors, HUAC, CBS and J. Edgar Hoover would not have been available. Lucille was also fully aware of this fact. She acknowledged that four of five years earlier, when she had not been such a well-known character, this scandal could have cost her her career93. Although the investigations on Lucille Ball were conducted between 1952 and 1954, only seven days were enough to calm the storm of accusations down. Owing to the fact that many influential people were financially involved in this case, Lucille had sufficient support to regain the confidence of the public. These seven days proved that it was not enough to convince the HUAC of her innocence, she had to convince the public that seemingly had a greater impact on her life.

\section{The presence of McCarthyism in Chaplin and Ball's Cases}

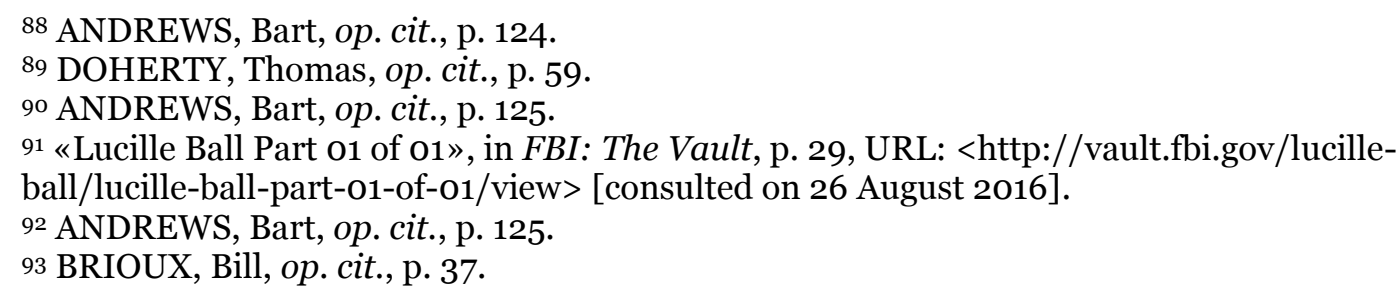


The differences of the cases give an insight how the methods of McCarthyism helped or prevented the subjects from clarifying their innocence and how they violated the democratic rights of people. Perhaps the most blatant method of McCarthyism was the use of insufficient evidence in order to level accusations at the subjects. Chaplin's case exemplifies this method perfectly. The first records on him let us know that he was accused of donating a thousand dollars to the Communist Party94. However, we also know that his bank account was monitored several times and nothing that could prove this assumption was found95. This fact, although it was recorded in the files, did not prevent the FBI to use the assumption as an ample proof of Chaplin's collaboration with Communists.

Charlie's presumed membership in the Communist Party of United States is another example of the use of unsubstantiated evidence. The FBI was informed that his membership had not been proven ${ }^{6}$, furthermore, Chaplin also refuted this accusation during the interview of the Immigration and Naturalization Service97. However, his membership still appears as a fact continuously in later files, moreover, investigations were initiated to gain information on his possible espionage activity ${ }^{98}$. The fact that even the MI5 opposed the charges of the FBI99 proves that the accusations against Chaplin were, in fact, based on unproven assumptions. This method of McCarthyism flagrantly violated the presumption of innocence which is a principle of the democratic criminal procedures against individuals.

As it is presented in the previous sections, the FBI stored up numerous material evidence against Lucille Ball. In her testimony, Lucille rebutted all the accusations and explained the origins of the material evidence by continuously referring to his grandfather ${ }^{100}$. This testimony was accepted by the HUAC and the FBI too, and later it was a basis on which Lucille could prove her innocence to the public by publishing it ${ }^{101}$. However, in Chaplin's case a different standpoint was adopted. Although, there was no crucial or sufficient evidence produced against Chaplin, he could not clear himself of

94 «Charlie Chaplin Part 07 of 10», in FBI: The Vault, p. 12, URL: <http://vault.fbi.gov/charliechaplin/charlie-chaplin-part-07-of-10/view $>$ [consulted on 22 July 2016].

95 Ibidem, p. 46.

96 Ibidem, p. 45.

${ }^{97}$ Ibidem, p. 237.

98 Ibidem, p. 203.

99 «KV2/3700», in The National Archives, 17 February 2012, p. 7.

100 «Lucille Ball Part 01 of 01», in FBI: The Vault, pp. 120-126, URL:

$<$ http://vault.fbi.gov/lucille-ball/lucille-ball-part-01-of-01/view> [consulted on 26 August 2016].

101 Ibidem, pp. 78-82. 
the unfounded accusations. In his testimony, he did not just refute these assumptions but also gave his opinion on Communism which reveals that he could not be a member of a Communist Party and he could not have ties with the Communist ideology ${ }^{102}$.

A record from January 1950 presents the viewpoint of the FBI on Chaplin's testimony: «the interview for the most part was inconclusive because Chaplin would either deny allegations, explain them in his own manner or state that he did not remember»103. If we carefully read through Lucille's testimony, it seems clear that during the interview she also did "deny" or "explain" the evidence presented against her, or she "did not remember". Thus, we can see that the FBI could not carry out an impartial inquiry into the cases. The biased investigations are another feature of McCarthyism which opposed and violated the Fourteenth Amendment to the U.S. Constitution which provides equal justice.

Another method of McCarthyism was the public accusation through the media. From Lucille Ball's case we know that the FBI and the HUAC were aware of the fact that the media could launch attacks against her, therefore, the second hearing was conducted which later cleared her of Communist accusations. However, in Chaplin's case the FBI used the media as a device against Charlie. They provided Louella Parsons and Hedda Hopper with information that they could use in their columns. These articles could influence the opinion of the public without any evidence. The FBI could not bring charges against Chaplin due to the lack of evidence, however, the press was not obligated to present substantial proof in their articles. Although it was possible, as it is now, to require correction notices, however, they could not mend the harm they had caused.

The public accusations also meant that the FBI publicised documents and data about the accused, however, this act violated the right to privacy. As it is mentioned previously, the FBI tried to collect all available information that could be used against Chaplin. The Paternity Case or the investigation on Chaplin's family were such private matters which ought to have been kept classified. The aforementioned letters show us that Chaplin's deportation was handled publicly and the FBI was able to play the public off against Chaplin ${ }^{104}$. This conclusion can be drawn from a letter written in August

102 "Charlie Chaplin Part 07 of 10», in FBI: The Vault, pp.237-249, URL:

<http://vault.fbi.gov/charlie-chaplin/charlie-chaplin-part-07-of-10/view> [consulted on 22 July 2016]; "Charlie Chaplin Part 08 of 10», in FBI: The Vault, pp. 1-11, URL:

<http://vault.fbi.gov/charlie-chaplin/charlie-chaplin-part-08-of-10/view> [consulted on 22 July 2016].

103 «Charlie Chaplin Part 08 of 10», in FBI: The Vault, p. 40, URL: <http://vault.fbi.gov/charliechaplin/charlie-chaplin-part-o8-of-10/view> [consulted on 22 July 2016].

104 Ibidem, pp. 62-65. 
1950. The sender confirms: «I heard over the radio today that we should turn in the names of any person or persons that we know to be subversive»105. Then, among many other famous persons' name, the sender list Chaplin in this letter.

Contrary to Chaplin, Lucille had the chance to decide over the publicising of the information of her case. Furthermore, in Lucille's case, not just the accusations, but the evidence and the testimony also went public. In that way, the public were fully informed and they were not taken in by false assumptions. As we know, in Chaplin's case, no evidence, just accusations were publicised.

The surveillance of innocent people was a common method of McCarthyism. The comparison of Lucille's and Chaplin's case shows that while Lucille's case was open from 1952 to December 1954, Chaplin was kept under surveillance between 1922 and 1978, which means that the FBI kept making records on him even after his death. At that point, it is necessary to emphasise the difference between conducting investigations and surveillance. Investigations are launched to determine the origin and the credibility of facts, or carried out to furnish further information and evidence on a subject; they are substantial and important proceedings in order to deliver justice. However, conducting surveillance on innocent people for the purpose of incrimination, cannot lead to justice. Chaplin was kept under surveillance because the FBI wanted to prevent his re-entry to the USA. This surveillance was based on false assumptions, which seems obvious if we consider that fifty-six years were not enough to find any incriminating evidence against him.

These methods have already revealed to us how democratic rights of individuals were trampled in the McCarthy era. As George Kennan stated: «Whoever could get his case before a court was generally assured of meeting there with a level of justice no smaller than at any other time in recent American history» ${ }^{106}$. However, neither Lucille's nor Chaplin's case was ever brought to court. It reveals a further method of McCarthyism: not providing a legal procedure that would give the opportunity for the accused to employ proper defence. This method was an essential part of McCarthyism; it was the precondition for the formerly mentioned methods.

Although the importance of personal acquaintances was mentioned previously, it is important to contrast them with Chaplin's case. Contrary to Ball's case, Chaplin did not depend on sponsors due to his $« \$ 30.000 .000$ worth of business»107. However, two

\footnotetext{
105 Ibidem, p. 61.

${ }^{106}$ Cit. in JOHNSON, Paul, Modern Times: The World from the Twenties to the Nineties, New York, Harper Collins, 1991, p. 460.

107 «Charlie Chaplin Part o8 of 10», in FBI: The Vault, URL: <http://vault.fbi.gov/charlie-

chaplin/charlie-chaplin-part-08-of-10/view> [consulted on 22 July 2016]. p. 249.
} 
other persons had a great effect on his case, one of them was Hedda Hopper. Hopper's columns on Chaplin reveal that she did not have a good opinion about him ${ }^{108}$. Thus, providing Hopper with information against Chaplin was equal to launching attacks on him. J. Edgar Hoover was the other prominent figure who connects the two cases. Though Lucille was backed by Hoover during the seven days of her scandal ${ }^{109}$, he did not help Chaplin's case. Hoover's response to letters from unidentified senders reveals his aversion to Chaplin. To a letter which raises again the question of Chaplin's deportation, Hoover replied: «I appreciate having the benefit of your observation in this matter»110. Later, Hoover urged to initiate investigation in order to prevent Chaplin's re-entry ${ }^{111}$. Hoover, as the director of the FBI had an enormous impact on investigation on Communist activities and seemingly he could not use this influence impartially. The fact that the results of these cases depended on the personal acquaintances, proves that the persecution methods of McCarthyism perverted the course of justice.

\section{Conclusion}

After scrutinizing Lucille Ball's and Charlie Chaplin's case, we can see the tactics and methods of McCarthyism which began to assert itself during the Second Red Scare. As a result of the increasing ideological threats of Communism against the USA during the early years of the Cold War, the mass hysteria that swept through the country provided a fertile ground on which McCarthyism could flourish. Ball's and Chaplin's cases adequately reflect that although McCarthyism was aimed to track Communist subversives down, its methods led to the severe persecution of innocent individuals.

Chaplin's case reveals that instead of careful investigation, the FBI initiated malicious attacks against Charlie after February 1950. Throughout the years, Chaplin was presented as an obstruction in the machinery of the American society which must be removed before too much damage could be done to this machinery. Although the FBI tried to associate Chaplin with Communism and kept him under close surveillance,

108 «Charlie Chaplin Part 01 of 10», in FBI: The Vault, p. 3, URL: <http://vault.fbi.gov/charliechaplin/charlie-chaplin-part-01-of-10/view> [consulted on 26 July 2016]; «Charlie Chaplin Part 03 of 10", in FBI: The Vault, p. 110, URL: <http://vault.fbi.gov/charlie-chaplin/charlie-chaplinpart-03-of-10/view $>$ [consulted on 28 July 2016].

${ }_{109}$ ANDREWS, Bart, op. cit., p. 124.

110 "Charlie Chaplin Part 08 of 10», in FBI: The Vault, p. 69, URL: <http://vault.fbi.gov/charliechaplin/charlie-chaplin-part-o8-of-10/view $>$ [consulted on 22 July 2016].

${ }^{111}$ Ibidem, p. 95. 
they could not catch him red-handed. Therefore, the FBI initiated investigations on his descent.

The records of the MI5 prove that the British Security Service did not find any evidence concerning this case. However, it is interesting how the MI5 responded to the accusation: «If they really want to whip up a case against Chaplin, they can read Pravda for themselves» ${ }^{112}$. This line reveals that the investigation on Chaplin's descent was only a pretext on which FBI could drag the MI5 into the anti-Communist witch-hunt.

Though Chaplin left the USA, he was not able to clear himself of the Communist accusations, and he was kept under surveillance until 1978. The FBI could not gather any credible evidence which could prove the unsubstantiated allegations of Charlie Chaplin's Communist ties.

In Lucille Ball's case, we can witness McCarthyism from a different standpoint. Ball's influential acquaintances helped her to get over the one-week-long trials and tribulations without any severe consequences for her life and career. While Chaplin was not given the opportunity to defend himself publicly, Lucille was provided with the assistance of the press. In Lucille Ball's case, the FBI and the HUAC did not serve as the prosecutor but rather as the defence since they supplied the essential information by which Lucille could prove her innocence in public.

Despite the fact that the accusations against Lucille were supported by numerous material evidence and by Rena M. Vale's testimony, the FBI claimed that they did not consider Lucille Ball as a security risk. They accepted Lucille's story about his grandfather, Fred Hunt, and they helped Lucille to prove her innocence in public. These facts prove that self-interest determined the outcome of the two cases and not the truth.

The two cases shed light on the methodology of McCarthyism. During the McCarthy era, investigations were conducted on the basis of insufficient evidence, false assumptions that the FBI could not support with relevant facts or documents, not even after a thorough investigation. Initially, the FBI and the HUAC were established to serve the American nation and to protect people from threats and attacks. However, during the McCarthy era, these institutions undermined the democratic principles of the nation. They violated the basic rights of individuals by which they caused irreparable harm to many people.

112 «KV2/3700», in The National Archives, 17 February 2012, p. 5. 


\section{* The author}

Erzsébet Árvay is a graduate student at Pázmány Péter Catholic University. She holds a Bachelor's Degree in English and American Studies from PPCU, and she is currently an MA student of Modern History. Her research interest primarily focuses on the memory processes of the Hungarian diaspora, with specific emphasis on the interdisciplinary approaches of trauma and motivated forgetting.

URL: < http://www.studistorici.com/progett/autori/\#Arvay >

\section{Per citare questo articolo:}

ÁRVAY, Erzsébet, «When Security Overrules Reason: McCarthyism in View of The Cases of Charles Chaplin and Lucille Ball», Diacronie. Studi di Storia Contemporanea : La voce del silenzio: intelligence, spionaggio e conflitto nel XX secolo, 29/12/2016,

URL:<http://www.studistorici.com/2016/12/29/arvay_numero_28/ >

\section{Diacronie Studi di Storia Contemporanea $\widehat{B}$ www.diacronie.it}

Risorsa digitale indipendente a carattere storiografico. Uscita trimestrale. redazione.diacronie@hotmail.it

Comitato di redazione: Jacopo Bassi - Luca Bufarale - Antonio César Moreno Cantano - Deborah Paci - Fausto Pietrancosta - Alessandro Salvador - Matteo Tomasoni - Luca Zuccolo

Diritti: gli articoli di Diacronie. Studi di Storia Contemporanea sono pubblicati sotto licenza Creative Commons 3.0. Possono essere riprodotti e modificati a patto di indicare eventuali modifiche dei contenuti, di riconoscere la paternità dell'opera e di condividerla allo stesso modo. La citazione di estratti è comunque sempre autorizzata, nei limiti previsti dalla legge. 